\title{
PROPERTY MARKET NATURE AND THE CHOICE OF PROPERTY PORTFOLIO DIVERSIFICATION STRATEGIES: THE NIGERIA EXPERIENCE
}

\author{
Abel OLALEYE \\ Department of Estate Management, Obafemi Awolowo University, Ile - Ife, Nigeria \\ E-mail: a_olaleye2000@yahoo.co.uk
}

Received 20 November 2006; accepted 30 August 2007

\begin{abstract}
With a focus on the Nigerian property market, this paper considered and empirically analyzed how property market nature and the perception of market players of some qualitative factors have impacted on choice of property portfolio diversification strategies. Questionnaires, backed up with interviews, were administered on 28 institutional property investors and 159 real estate practitioners in three commercial nerve centres of Nigeria, namely, Lagos, Abuja and Port-Harcourt metropolitan areas. The frequency distribution analyses' results revealed that the Nigerian property market was an emerging one and, as it is expected, there was dearth of time series data while investors in the market were small time institutional investors. Using mean rating on a 4-point rating scale, the study found six factors, arising from the nature of the property market, as the significant factors impacting on choice of diversification strategies. These are: the investors' overall expectation of the benefits of diversification scheme, the need to reduce management operating costs, management convenience, operating environment, market players' education and knowledge of alternative diversification techniques and availability or otherwise of data in the market. The result of cross tabulation and Chi-square test also indicated that there was a statistically significant relationship between educational qualifications of practitioners and their choice of diversification strategies.
\end{abstract}

KEYWORDS: Property portfolio; Diversification strategies; Property market nature; Choice factors; Nigeria

\section{INTRODUCTION}

Arising from the need to address the problems of risk in investment decision, the pattern of investment all over the world has changed substantially and investors are looking for opportunities to diversify their portfolios even on a global scale (Hoesli and MacGregor, 2000 and Lim et al., 2002). The reason for this is not far fetched. Diversification gives investors the benefit of varying in- vestment possibilities in order to minimise the encompassed risks and maximise the return therefrom. The concept describes the combination of investments within the same asset class. Thus, diversification achieves the same objectives as asset allocation: maximising return with minimum risk. However, with diversification, the concern is with reducing the specific or unsystematic risk, while asset allocation focuses on reducing the systematic risk.

International Journal of Strategic Property Management

ISSN 1648-715X print / ISSN 1648-9179 online @ 2008 Vilnius Gediminas Technical University http://www.ijspm.vgtu.lt

DOI: 10.3846/1648-715X.2008.12.35-51 
Meanwhile, property market is localised and products are heterogeneous, real estate market place is an amalgamation of a least hundred, if not thousands, of specific market segments that have their own conditions, problems and opportunities. Thus, diversification as used in this paper is relevant to the concept of minimising the systematic and unsystematic risks within real estate investment market.

Since Markowitz (1952, 1959) foundation works on Modern Portfolio Theory (MPT), an important issue that has occupied the minds of professionals and researchers, especially in the developed world, is how to ensure the selection of best strategy in portfolio diversification. And, in realisation of the fact that investment of any type has two principal components (anticipated risk and return); investors' and researchers' interests on portfolio diversification have focused mainly on analysing the return/risk levels of available alternatives. The choice between these available alternatives, which range from a simple rule of thumb to a full scale quadratic programming techniques, can be grouped into two main approaches. These are (i) naive diversification which is based purely on a subjective estimate of portfolio's benefits and (ii) MPT based quantitative techniques such as mean-variance analysis, constant correlation analysis and single index model.

Generally, investors' and practitioners' choice of portfolio diversification strategies is influenced by the return/risk pay-off of the different strategies/portfolios. In other words, strategy that gives the portfolio with the best return/risk ratio is to be preferred by a rational investor (Hargitay and Yu, 1993; Ajayi, 1998; Hoesli and MacGregor, 2000). This explains why researchers' efforts on property portfolio diversification strategies have focused mainly on examining the benefits due to diversification by analysing, in quantitative term, the return/risk attributes of the strategies/portfo- lios (see for example Mueller and Laposa, 1995; Brown et al., 2000; Lee, 2005; Olaleye et al., 2006).

Recently however, the quest to explain the choice of property portfolio diversification strategies has tended to focus on qualitative factors arising from the nature of property market aside the issue of return/risk attributes. This is because the study by Barry et al. (1996) and Olaleye (2005) opened the possibility that other factors, arising from the nature of a particular property market, could impact on decision makers' choice of diversification strategies aside the issue of return/risk benefit. In addition, comments of authors such as Del Casino (1995), Keogh and D'Arcy (1994), D'Arcy and Keogh (1998), Hargitay and Yu (1993), Brown (1997), Ajayi (1998), Hoesli and Macgregor (2000) lend credence to the fact that lack of easy access to good time-series data or market index cum lack of extensive information flow and research activities could discourage usage of MPT based diversification. The authors' submissions also suggest that lack of adequate knowledge of quantitative techniques of diversification, arising from the complexity of the methods and the less sophisticated nature of the property market with its associated institutions and networks, might discouraged the use of MPT based diversification strategies. Also, the acceptance or otherwise of the quantitative techniques of diversification might be a major factor limiting choice of MPT based strategies in an emerging real estate market like the Nigerian property market. Lummer et al. (1994) have opined that investors are loath to invest on the basis of trading and allocation system they do not understand. Hargitay and $\mathrm{Yu}$ (1993) had earlier noted that the interpretation of quantitative information and its use required the understanding of a number of mathematical and statistical procedures, the complexity of which could be quite daunting for investors. These studies have thus produced theoretical evidence which tends to 
suggest the presence of other factors capable of limiting/impacting on market players' (investors and practitioners) choice of diversification strategies in a particular property market. In other words, these studies, though lacked in empirical evidence, have set out a body of theory and evidence to suggest that the property market environment, nature and practice and the way the decision makers in the market perceived some qualitative factors would influence choice of diversification strategies apart from return/risk attributes of portfolios/strategies. Therefore, there is need to provide empirical answer to the question of how property market nature and the perception of market players of some qualitative factors of diversification have impacted on the choice of portfolio diversification strategies.

Except for the study of Barry et al. (1996) that have considered the issue of qualitative factors influencing choice of diversification strategies, other empirical studies in the past have concentrated only on analyzing return/ risk attributes of various diversification strategies. Examples of such studies include Miles and McCue (1982), Hartzell et al. (1986), Hartzell et al. (1987), Grissom et al. (1987), Giliberto and Hopkins (1990), Mueller (1993), Mueller and Laposa (1995), Williams (1996), Wolverton et al. (1998), Cheng and Liang (2000), Viezer (2000) and Brown et al. (2000). Others include Lee (2005), Olaleye et al. (2006) and Adair et al. (2006). The benefits (and disbenefits), in terms of return/risk attributes, of international portfolio diversification have also been examined by Steinert and Crowe (2001), Conover et al. (2002) and Bond et al. (2003). However, apart from the fact that Barry et al. (1996) only identified the qualitative factors potentially limiting investors' diversification opportunities, the study used a data set which may not be useful as proxies for the underlying real estate investment environment in emerging markets like Nigeria. The authors' definition of emerging market (as adopted from the International Finance Corporation (IFC)) as a capital market in a developing nation is only relevant to a developing nation's market where real estate is already incorporated into capital market, as against a non-integrated real estate market as used in this paper. Thus, there is still lack of evidence of the market/ qualitative factors potentially impacting on decision makers' choice of diversification strategies in undeveloped real estate market. This paper addressed this issue with a focus on the Nigerian property market. It is hoped that, with the advent of globalization, the paper will also be a source of useful information for an understanding of the Nigerian property market by international investors. It is also capable of providing ways by which property portfolio managers can improve on their diversification selection decisions.

\section{DATA SOURCES AND METHODOLOGY}

The framework upon which this paper achieves its objectives was based on the theoretical expectations suggested by Del Casino (1995), Barry et al. (1996) and Olaleye (2005). Such potential factors that are capable of impacting on decision makers' choice of diversification strategies can be categorized under three main headings. These are (i) investors return and risk consideration (ii) market players (investors and practitioners) characteristics and (iii) market characteristics. However, only the characteristics of the market and that of the market players were the focus of this study since studies in the past have focused more on the first aspect. Variables considered under these two characteristics (factors) include:

\section{A. Market Characteristics}

(i) The availability or otherwise of data in constructing diversification schemes.

(ii) Operating environment and the ease of dealing with some states and local governments. 
(iii) The effects that certain areas might have on the returns from portfolio.

(iv) The issue of convenience in managing the constituent properties of a portfolio.

(v) The need to reduce management operating costs

(vi) Vulnerability of some areas to natural or artificial disasters.

(vii) Investors' overall expectation of the benefits of diversification scheme/strategies.

B. Market Players Characteristics.

(viii)The ability/accessibility or lack of it to computer programs for portfolio analysis.

(ix) Education and experience of market players with alternative diversification techniques.

The practitioners' and investors' perception of these factors as they affect their choice of diversification strategies was measured on a 4-point likert scale from 0 (not important) to 3 (very important). The study of investors focused on institutional property companies, while practitioners comprised of the estate surveying and valuation firms in the country. Twenty-eight (28) institutional property investors and 159 real estate practitioners were studied. Data, on the characteristics of the sampled population and what they considered as the factors impacting on their choice of diversification strategies, were collected with the use of questionnaires backed up with interviews.

The property markets in Nigeria, following from the vibrancy and active nature of each market/location, can be classified into two major categories, namely, the primary and secondary markets. The secondary markets include the medium and low rental and capital value markets. The property markets of Ibadan, Ondo, Enugu, Kano and Minna can be classified into this category. The primary markets are the high rental and capital value markets where there is very active and dynamic market situation. These markets include the three main commercial nerve centres of Nigeria, that is, Lagos, Abuja and PortHarcourt metropolitan areas. And as it is expected, approximately $61 \%$ of real estate practitioners in the country have their head offices located in these three locations, while about $60 \%$ of real estate transactions in Nigeria are conducted in the areas. As a result of this, the data collections were concentrated on Lagos, Abuja and Port-Harcourt metropolitan areas. In addition, the major reasons for selecting these metropolitan areas and for concentrating most of the analysis on institutional property investors and estate surveying firms are: (1) it is expected that these areas would have an active property portfolio diversification practice; (2) data collected from these areas would form a general and true representation of what is obtained in the whole country; and (3) Estate Surveyors, as property experts, should have a better understanding of the peculiar characteristics of property investment and the market; and be able to apply this in the process of real estate diversification analysis than other professionals.

The sample size of the property investors represents all the institutional property companies identified based on the examination of the Property Finder, a directory of Real Estate Business in Nigeria (2002 Edition) and the initial discussion with professionals in practice. Samples of 5, 1 and 22 companies, respectively, were studied in Abuja, PortHarcourt and Lagos metropolitan areas. In the case of the practitioners, approximately $60 \%$ of the constituent population in each of the three locations was sampled based on the 2002 Edition of the register of the professional body. For example, 136 (59.6\%) of the 228 Estate firms in Lagos were sampled. In Abuja, 9 firms were sampled, representing $60 \%$ of the entire population (15). The total coverage of the Estate firms in Port-Harcourt represented 
$60.86 \%$. Fourteen (14) of the total twenty three (23) firms were studied. This shows that 159 questionnaires were administered on real estate practitioners which represented $59.77 \%$ of the total 266 Estate Surveying firms in the three areas studied. This represented as well, $36.22 \%$ of the total 439 Estate firms in the country. The total responses were $12(43 \%)$ and $54(34 \%)$ for property investors and estate surveying firms respectively. The data collected were analysed with the use of frequency distribution, mean and standard deviation measures and Chi-square test.

\section{RESULTS}

In presenting the results of the questionnaire survey, the paper first examined the diversification strategies given highest consideration in the Nigerian property market among the two broad categories; that is the naive and MPT based diversification strategies.

\subsection{Diversification strategies adopted in the Nigerian property market}

As shown in Table 1, all of the institutional property investors adopted naive diversification strategies in their practices. With respect to the practitioners, they were using both naive and Modern Portfolio Theory (MPT) based diversification strategies when advising their clients on diversification decisions (see Table 1).

Specifically, Table 1 shows that $33(61.1 \%)$ of the practitioners were adopting naive diversification strategies. Nine (9) (16.7\%) adopted MPT based strategies, while, $14.8 \%$ were adopting both methods to advise their clients. This therefore shows that naive diversification were the preferred strategies in the Nigerian property market. Two reasons can be suggested for this finding: (i) modern portfolio theory based (efficient portfolio) diversification strategies involved complex mathematics; whereas, investors and practitioners alike might not have been trained on the techniques of these strategies; (ii) investors generally are known to be reluctant of investing on the basis of trading and allocation system that they do not understand. In addition, small size of investors' portfolios might make the use of MPT based diversification impracticable. Also, lack of time series data for explicit analysis involved in efficient portfolio diversification might have also influenced this finding. To establish these facts however, the paper examined the nature of the Nigeria property market in the subsequent sections.

Table 1. Diversification strategy adopted by real estate investors and practitioners

\begin{tabular}{lllll}
\hline $\begin{array}{l}\text { Diversification } \\
\text { strategy }\end{array}$ & Investors & Practitioners & \\
\cline { 2 - 5 } & Response level & $\begin{array}{l}\text { Percentage of } \\
\text { response }(\%)\end{array}$ & Response level & $\begin{array}{c}\text { Percentage of } \\
\text { response }(\%)\end{array}$ \\
\hline Naive & 12 & 100 & 33 & 61.1 \\
MPT based & - & - & 9 & 16.7 \\
Both & - & - & 8 & 14.8 \\
None & - & - & 4 & 7.4 \\
No response & - & - & - & - \\
Total & 12 & 100 & 54 & 100 \\
\hline
\end{tabular}

Source: Field data analysis, 2004 


\subsection{The nature/characteristics of the Nigeria property market}

In examining the characteristics of the $\mathrm{Ni}$ gerian property market, emphasis is placed on age of the property companies and the size of their portfolios. The latter is considered in terms of numbers and values of property owned. The paper also examined the sophistication of the market in terms of the availability and usage of information and the training of the sampled population by probing into their qualifications and professional developments. The aim is to establish the nature or maturity of the Nigerian property market and thereby unravel the factors that have influenced the choice of naive strategies in property portfolio diversification as found out in the previous section above.

\subsubsection{Age of the institutional property companies/investors}

The result in Table 2 shows that $8.3 \%$, $41.7 \%, 41.7 \%$ and $8.3 \%$ of the companies were aged between 1 and 5 years, 6 to 10 years, 11 to 15 years and 21 years and above respectively. This indicated that greater percentages $(83 \%)$ of the companies sampled were aged between 6 and 15 years. Given this outcome, one may conclude that institutional real estate companies in Nigeria were of young ages.
This result points to the fact that the idea of institutional real estate investment is recent in Nigeria and that the property market might be expected to be an emerging market.

\subsubsection{Numbers of properties owned by property investors and the portfolios' value}

From the results in Table 3, it is revealed that at least $58.3 \%$ of the companies owned between 1 and 15 properties. Only 8.3\% had in their portfolios between 16 and 30 properties. Similarly, $16.7 \%$ had between 31 and 45 properties in their portfolios and indeed another 8.3\% had properties up to between 106 and 120 in number. Thus, it can be deduced that most property investors or companies in the Nigerian property market had just between 1 and 15 properties in their portfolios.

As shown in Table 3 as well, the study revealed that greater percentages $(58.3 \%)$ of the sampled investors had their portfolio value worth a maximum of N500M. This is just about $\$ 3.9 \mathrm{M}$ at the present exchange rate of about N128 to $\$ 1$. This thus confirmed that investors in Nigeria were small time institutional investors especially when compared to their counterparts in U.S. who had, within one property class alone, properties that worth $\$ 100 \mathrm{M}$ (Zeiring and Mclntosh, 1999). These results

Table 2. Age of institutional property companies sampled

\begin{tabular}{lll}
\hline Age (years) & Response frequency & Percentage of response \\
\hline $1-5$ & 1 & 8.3 \\
$6-10$ & 5 & 41.7 \\
$11-15$ & 5 & 41.7 \\
$16-20$ & - & - \\
21 and above & 1 & 8.3 \\
Total & 12 & 100 \\
\hline
\end{tabular}

Source: Field data analysis, 2004 
Table 3. Average number of properties in investors' portfolios and the portfolios' value

\begin{tabular}{|c|c|c|c|c|c|}
\hline $\begin{array}{l}\text { Number of } \\
\text { properties }\end{array}$ & $\begin{array}{l}\text { Response } \\
\text { frequency }\end{array}$ & $\begin{array}{l}\text { Percentage of } \\
\text { response }\end{array}$ & $\begin{array}{l}\text { Portfolio worth } \\
\text { (Capital value) }\end{array}$ & $\begin{array}{l}\text { Response } \\
\text { frequency }\end{array}$ & $\begin{array}{l}\text { Percentage of } \\
\text { response }\end{array}$ \\
\hline $1-15$ & 7 & 58.3 & Below N100M & 2 & 16.7 \\
\hline $16-30$ & 1 & 8.3 & $\begin{array}{l}\text { Between N101 } \\
\text { and N500M }\end{array}$ & 5 & 41.7 \\
\hline $31-40$ & 2 & 16.7 & $\begin{array}{l}\text { Above N1.0b to } \\
\text { N2.0b }\end{array}$ & 1 & 8.3 \\
\hline $106-120$ & 1 & 8.3 & $\begin{array}{l}\text { Above N2.0b to } \\
\text { N3.0b }\end{array}$ & 1 & 8.3 \\
\hline No response & 1 & 8.3 & $\begin{array}{l}\text { Above N3.0b to } \\
\text { N4.0b }\end{array}$ & 1 & 8.3 \\
\hline \multirow[t]{3}{*}{ Total } & 12 & 100 & Above N8.0b & 1 & 8.3 \\
\hline & & & No response & 1 & 8.3 \\
\hline & & & Total & 12 & 100 \\
\hline
\end{tabular}

Source: Field survey, 2004

might be as a result of the young nature of the companies in terms of age and, especially, the lack of easy access to large capital fund for long term investment in Nigeria. It should be noted that only one of the property investors in Nigeria had access to funds through the capital market while others were relying on direct funding from loans and equity funds. The small size of many of the investors' portfolios might have discouraged the use of MPT based diversification strategies.

\subsubsection{Academic qualifications and professional development of the investors and practitioners}

The summary of responses on academic qualifications and professional development of respondents are as indicated in Tables 4 and 5. From Table 4, it is conclusive that greater percentages $(58.3 \%)$ and $(70.4 \%)$ of the investors and practitioners, respectively, held Bachelor of Science (B.Sc.), while, 3(25\%) and $7(13 \%)$ of the investors and practitioners,

Table 4. Highest academic qualifications of staff of the property companies and practitioners

\begin{tabular}{lllll}
\hline Qualifications & Investors & Practitioners & \\
\cline { 2 - 5 } & Response frequency & $\begin{array}{l}\text { Percentage of } \\
\text { response }\end{array}$ & Response frequency & $\begin{array}{l}\text { Percentage of } \\
\text { response }\end{array}$ \\
\hline H.N.D. & 2 & 16.7 & 9 & 16.7 \\
B.Sc & 7 & 58.3 & 38 & 70.4 \\
M.Sc & 3 & 25 & 7 & 13 \\
Total & 12 & 100 & 54 & 100 \\
\hline
\end{tabular}

Source: Field data analysis, 2004 
respectively, held Master of Science (M.Sc) all in Estate Management.

The responses of the investors and practitioners on the numbers of training conferences and/or workshops, on property portfolio diversification, they have attended in the last five years, are reported in Table 5. The analysis established that greater percentages of the two groups have not been developing their knowledge in the area of portfolio analysis and diversification.

Specifically, it is shown in Table 5 that 5 $(41.7 \%)$ of the respondents among the investors and $34(63 \%)$ of the practitioners have not attended any conference or seminar in the area of portfolio diversification within the last five years. Another $5(41.7 \%)$ and $15(27.8 \%)$ of the investors and practitioners respectively have attended between 1 and 5 of such conferences while $2(16.7 \%)$ of the investors and $5(9.3 \%)$ of the practitioners attended between 6 and 10 conferences. This suggests that most investors and practitioners alike might not have been trained on the techniques of MPT, since the immediate previous analysis in this section have shown that most of the respondents held Bachelor of Science (Estate Management) degree only. Meanwhile, the author's observation of the curricula of some universities showed that, for most of the universities, the concept of portfolio theory and diversification are taught at the postgraduate level. This might have influenced respondents' decisions towards naive diversification strategies since the methods require little or no pre-requisite knowledge before they could be used.

\subsubsection{Relationship between practitioners academic qualification and their choice of diversification strategies}

For a better establishment of the above, the study further examined the relationship that existed between the practitioners' educational qualifications and experience on one hand and their choice of diversification strategies on the other. The result of cross tabulation and Chisquare test indicated that there was a statistically significant relationship between educational qualifications and practitioners' choice of diversification strategies. For example, the analysis in Table 6 establishes that 7 (77.78\%) of the 9 Higher National Diploma certificate holders used naive diversification strategies. Whereas, only $1(11.11 \%)$ of them was using MPT based strategies, while $1(1.11 \%)$ was using both strategies. In similar vein, 23 $(60.53 \%)$ of the 38 B.Sc graduates preferred naive diversification strategies, while 7 $(18.42 \%)$ of them used both naive and MPT based diversification strategies. On the contrary, out of the respondents with M.Sc degrees (7 in all), $4(57.14 \%)$ claimed that they were

Table 5. Number of conferences, workshops or seminars attended by investors and practitioners

\begin{tabular}{lllll}
\hline $\begin{array}{l}\text { Number of } \\
\text { conferences }\end{array}$ & Investors & Practitioners & \\
\cline { 2 - 5 } & Response level & $\begin{array}{l}\text { Percentage of } \\
\text { response }\end{array}$ & Response level & $\begin{array}{l}\text { Percentage of } \\
\text { response }\end{array}$ \\
\hline None & 5 & 41.7 & 34 & 63 \\
$1-5$ & 5 & 41.7 & 15 & 27.8 \\
$6-10$ & 2 & 16.7 & 5 & 9.3 \\
Total & 12 & 100 & 54 & 100 \\
\hline
\end{tabular}

Source: Field data analysis, 2004 
Table 6. The relationship between the practitioners' educational qualifications and their choice of diversification strategies

\begin{tabular}{llllll}
\hline \multirow{2}{*}{ Qualifications } & \multicolumn{2}{l}{ Diversification strategies } & & \\
\cline { 2 - 6 } & Naive & MPT based & Both & None & Total \\
\hline HND & 7 & 1 & 1 & - & 9 \\
B.Sc & 23 & 4 & 7 & 4 & 38 \\
M.Sc & 3 & 4 & - & - & 7 \\
Total & 33 & 9 & 8 & 4 & 54 \\
\hline
\end{tabular}

Source: Field data analysis, 2004

Table 7. The relationship between the practitioners' year of post qualification experience and their choice of diversification strategies

\begin{tabular}{|c|c|c|c|c|c|}
\hline \multirow[t]{2}{*}{ Experience } & \multicolumn{5}{|c|}{ Diversification strategies } \\
\hline & Naive & MPT based & Both & None & Total \\
\hline None & 1 & - & - & - & 1 \\
\hline $1-5$ years & 14 & 3 & 4 & 1 & 22 \\
\hline $6-10$ years & 5 & 3 & 2 & 2 & 12 \\
\hline 11-16years & 4 & 2 & - & - & 6 \\
\hline 16 and above & 9 & 1 & 2 & 1 & 13 \\
\hline Total & 33 & 9 & 8 & 4 & 54 \\
\hline
\end{tabular}

Source: Field data analysis, 2004

using MPT based diversification strategies. It can thus be inferred that, the lower the academic qualification of practitioners, the higher the likelihood of using naive diversification, while the higher the qualification, the higher the likelihood of using MPT based diversification strategies. Using Chi-square test, the relationship between practitioners' qualifications and their choice of diversification strategies was found to be significant at $93.4 \%$ confidence level (0.066 level of significance). This result confirmed the outcome of the preceding analyses in this paper. However, no clear relationship was found between the practitioners' years of post qualification experience and their choice of diversification strategies (Chi-square value was only significant at 0.858 level) (See Table 7).
The foregoing analyses support the fact that investors and practitioners in the Nigerian property market were using naive diversification strategies in their portfolio selection decisions mainly because of the small size of many of the investors' portfolios. Also, there is evidence to suggest that the respondents might not have been trained on the techniques of MPT based diversification. However, it has been noted earlier in this paper that without the maintenance of a comprehensive data and information base in the property market and the economy at large, the practice of MPT based diversification analysis would be impossible. In other words, even if the investors and practitioners are well vast in the knowledge of the strategies of MPT, lack of good time series data for a meaningful comparative analysis 
may render the strategies impracticable. As such, the next analysis tries to investigate the availability of performance indices and their usage.

\subsubsection{Availability and usage of information}

The paper examines the sources of information employed by investors and practitioners in their diversification analysis to establish the presence or otherwise of free flow of information. In doing this, questions were asked that required the respondents to rank certain pre-conceived sources in their order of usage. The analysis in Table 8 shows that the most frequently used sources of data and information for real estate diversification decisions were in-house data from files and information from other practitioners. The use of inhouse files as a source of information ranked first and second among the investors and estate firms respectively. In similar vein, the use of information from practitioners ranked second and first, respectively, among the investors and the estate firms. Market survey was rarely used, while databank on return indices (either individual company's index or centralised one) was not in use. This result is not unexpected because Olaleye (2004) had earlier shown that there was no centralised databank or market index in the Nigerian property market, a condition which was attributed to the secrecy attached to property transactions data in Nigeria. Therefore, this dearth of data and information in the property market might have also influenced the use of naive diversification strategies.

\subsection{Investors' and practitioners' opinion on factors influencing choice of diversification strategies}

As part of the objectives of the paper, this section assessed the respondents' perception of the factors conceptualized to be impacting on choice of diversification strategies. Responding investors and practitioners were asked to rank the factors, on a 4-point rating scale in terms of most important, important, of less importance and not important, depending on their assessment of the importance of the factors to their diversification decisions. The ranking were then assigned scores of 3,2, 1 and 0 for most important, important, of less importance and not important respectively. The analyses, which were resolved by means of frequency counts and means, are as indicated in Tables $9 \mathrm{a}$ and $9 \mathrm{~b}$ for investors' and practitioners' responses respectively.

The results of the means in Table 9a revealed that the responding investors believed that their overall expectation of the benefits of diversification schemes had the greatest influence on their choice of diversification strategies. This factor ranked first in the investors' ranking with a mean value of 2.083 . The need to reduce operating costs and the availability or otherwise of data/information required for constructing a diversification scheme were ranked second and third respectively. Their mean values are 1.917 and 1.750 . The issue of the convenience in managing the different constituent properties in a portfolio was ranked fourth in the order of importance by the investors, while they considered the effect that certain areas might have on their portfolio returns as the fifth important factors in the choice scale (see Table 9a for details).

With regards to the practitioners, the results in Table 9b showed that the need to consider the investors' overall expectation of the benefits of diversification schemes was also ranked as having the greatest influence on practitioners' choice of diversification strategies. (Mean $=2.435)$. However, unlike the ranking in the investors' choice scale, the need to consider the effect that certain areas might have on portfolio return (which ranked $5^{\text {th }}$ among the investors) was seen as the factor having the second most important influence 


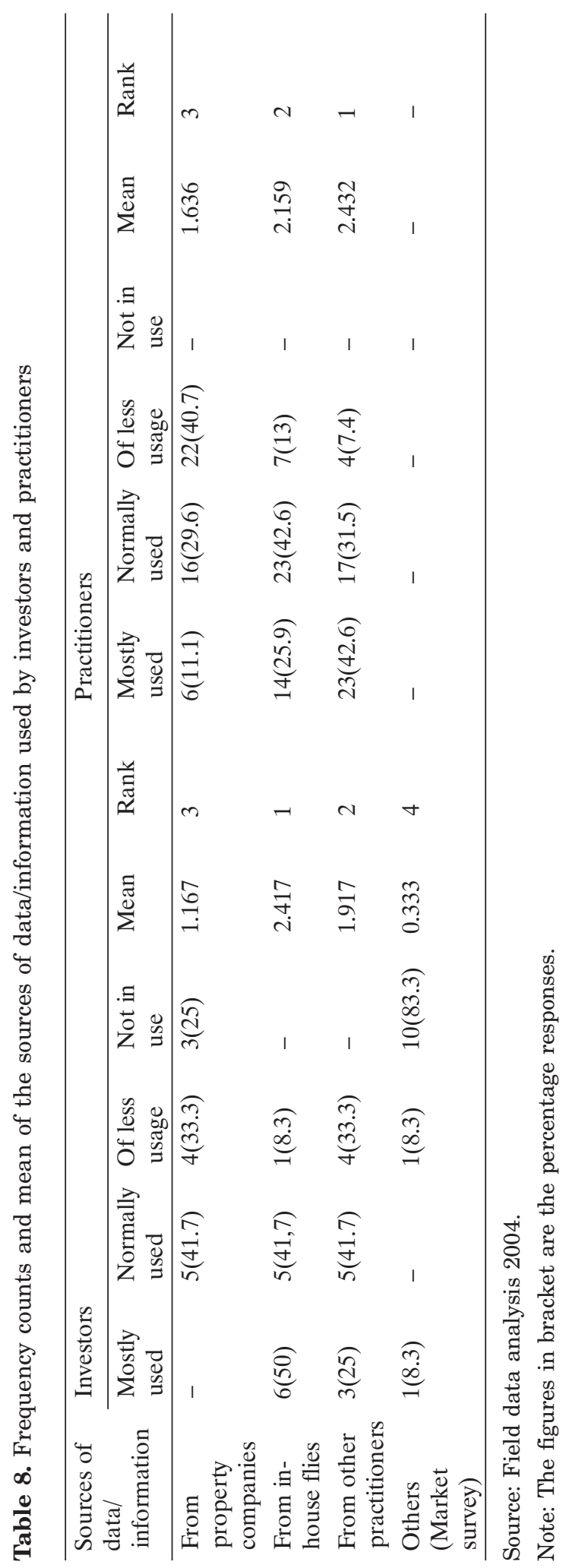




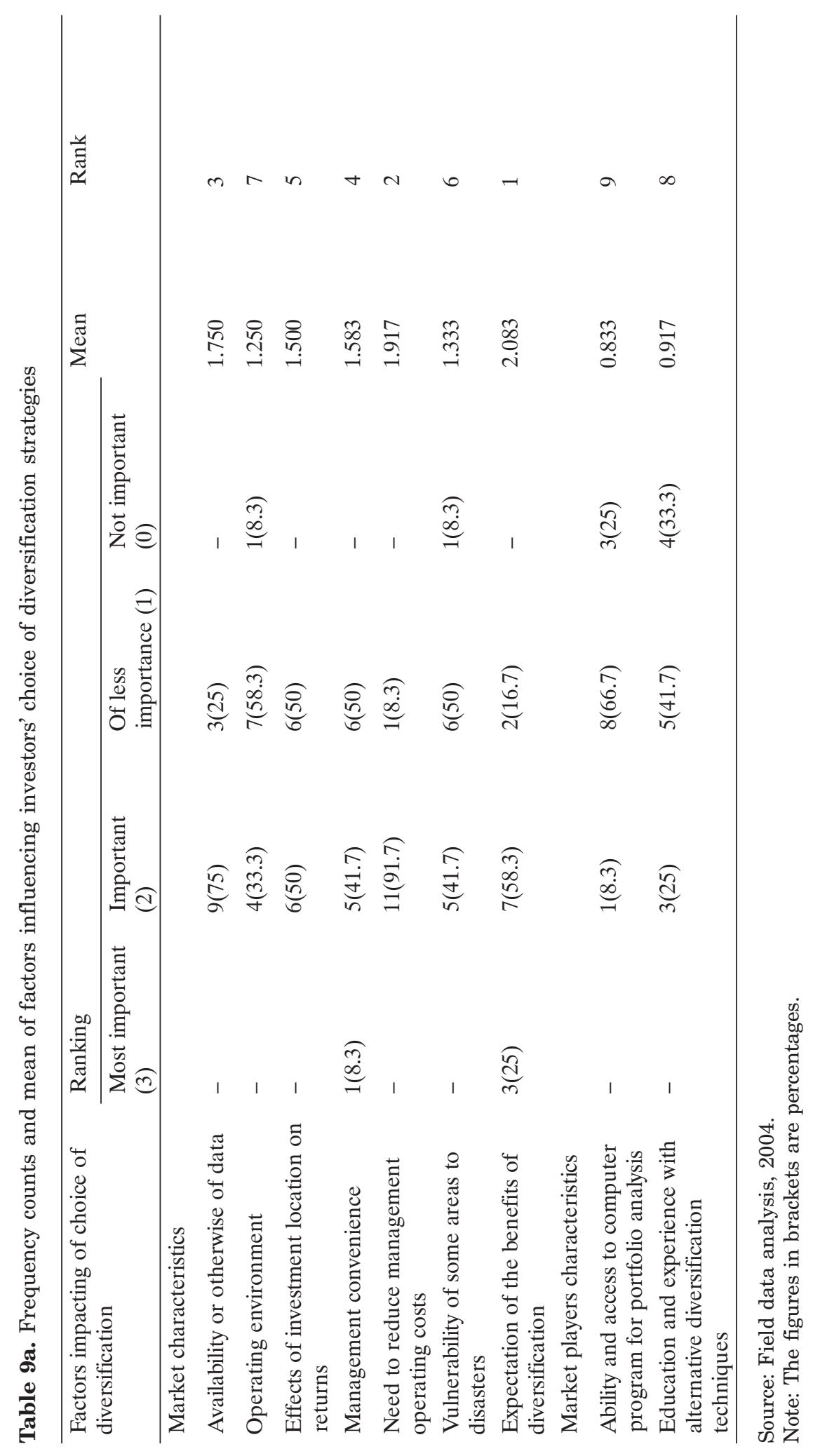




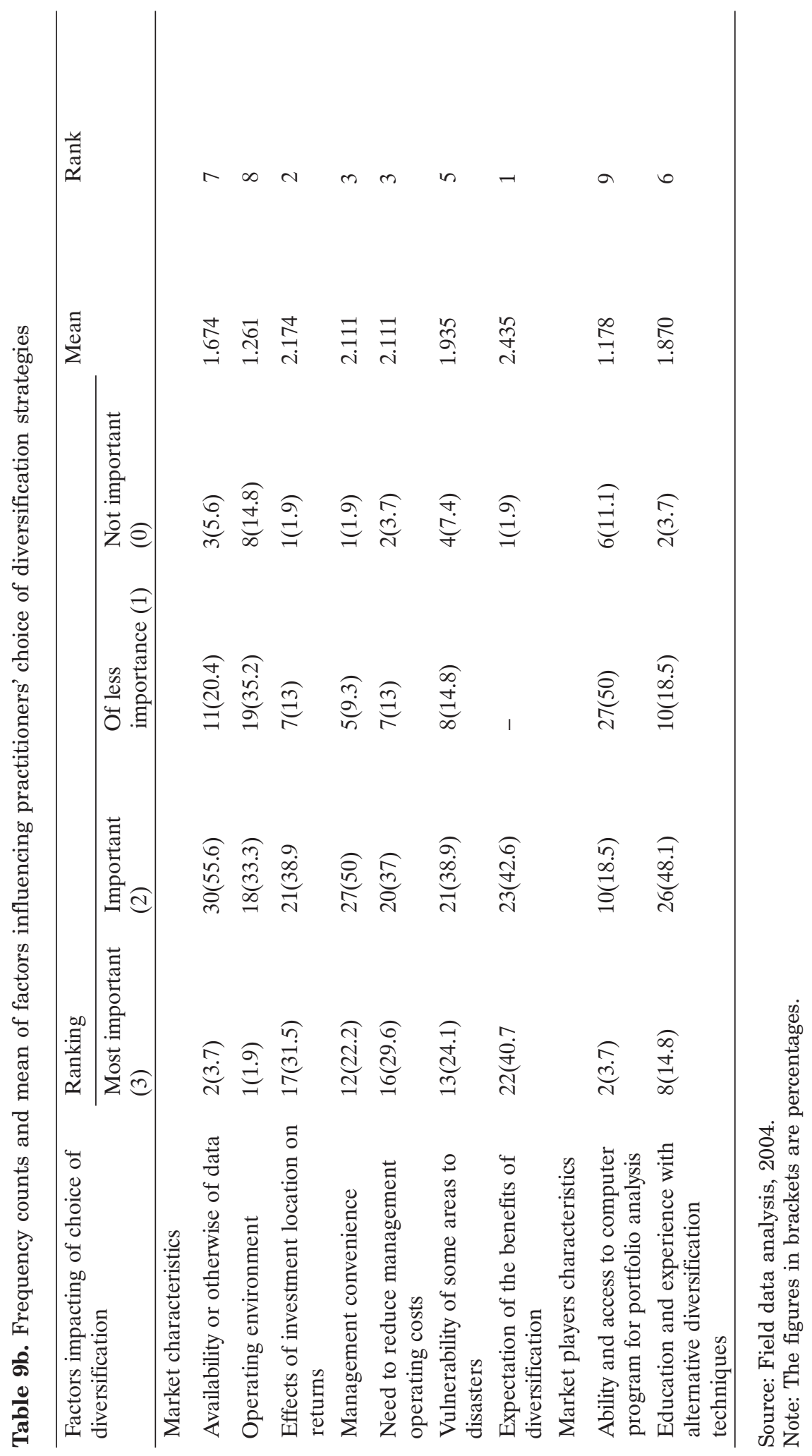


on the choice of diversification among the practitioners. The need to reduce operating costs on a portfolio and the issue of convenience in managing the different constituent properties of the portfolio were both ranked third by the practitioners.

From these results, six main factors are considered as having, at least, important influence on the market players' choice of diversification strategies given their mean values which ranged between 1.750 and 2.435. These are: (i) the investors' overall expectation of the benefits of diversification strategies, (ii) the need to reduce management operating costs of a portfolio, (iii) the issue of convenience in managing the constituent properties, (iv) the effects that certain areas might have on the returns from portfolio, (v) market players' education and knowledge of alternative diversification techniques and (vi) the availability or otherwise of data in constructing diversification schemes. Factors such as, the ease of dealing with some states and local governments, the vulnerability of some areas to natural or artificial disasters and market players' ability and accessibility or lack of it to computer programs for portfolio analysis were found to be of less importance to diversification decisions in the Nigerian property market.

\section{CONCLUSIONS}

In the paper's examination of how property market nature has impacted on choice of property portfolio diversification strategies, the results of the analysis showed that the Nigerian property market was an emerging market. Investors' portfolios were found to be of small sizes, while there was dearth of transaction data in the market. The results also showed that greater percentages, $(58.3 \%)$ and $(70.4 \%)$, of the investors and practitioners respectively held B.Sc Estate Management degree certificate. Only (25\%) and (13\%) of the investors and practitioners, respectively, had additional qualification in the form of M.Sc and M.B.A. The results also showed that greater percentages of the two groups have not been developing their knowledge, by way of attending conferences, workshops and so on, in the area of portfolio analysis and diversification. In addition, the results of the relationship between the practitioners' educational qualifications and their choice of naive diversification strategies showed that the lower the academic qualification, the likelihood of using naive strategies and the higher the qualification the likelihood of using MPT based strategies. The results of the investors' and practitioners' perception of how the factors influencing diversification choices have affected their decisions showed that: (1) investors are risk averse and will prefer more return to less and less risk to more; (2) the underdeveloped nature of the Nigerian property market, judging from the lack of information and the market players' low level of education and knowledge of MPT based diversification techniques have influenced the choice of naive strategies.

As a result of the foregoing, it is considered that the following need to be addressed for the Nigerian property market to move forward and benefit from the ever changing global trends in the profession.

There is a clear need for improvement in the recording and availability of transaction data individually as institutional property company and collectively as a profession. There is need to ensure a speedy actualisation of the current efforts of the Nigerian Institution of Estate Surveyors and Valuers aimed at ensuring the compilation of historical and time series data or centralised database in Nigeria. This will allow a near accurate comparative analysis at national, regional and metropolitan/local market levels. A move towards this maturity will mean that a micro-real estate specific data derived from local markets information could be used to develop property trans- 
action and performance indices. Also, the present secrecy and confidentiality attached to property transactions data should be relaxed to allow for a comprehensive data to be collated and analysed on a continuous basis.

To encourage a speedy growth in the size of property companies' portfolios, it is considered necessary that government should create enabling environment for the operation of finance sources such as securitisation and unitisation to ensure availability of long term capital for real estate investment. These methods have been the global trends for mobilising long-term funds for rapid and sustainable real estate development.

It is also considered that the Estate Surveyors and Valuers Registration Board of Nigeria (ESVRABON) in conjunction with the Nigerian Institution of Estate Surveyors and Valuers (NIESV) should come out with guidelines on real estate portfolio diversification practice to ensure better diversification practice and uniformity of approach. The guidelines should be such that encourage a comprehensive property portfolio appraisal system and encourage the use of quantitative/analytical approaches in diversification evaluation especially in the long run. A guideline committee should be saddled with this responsibility.

It is also suggested that both the Estate Surveyors and Valuers Registration Board of Nigeria and the Nigerian Institution of Estate Surveyors and Valuers on one hand, and our educational institutions on the other, must assist in closing the gap in real estate portfolio diversification theory and practice in the country. To achieve this, the education of those currently being and yet to be trained practitioners requires that the curricula of our educational institutions of higher learning should provide opportunity for estate management students to be trained on MPT based quantitative diversification analysis at the undergraduate level. The education of those currently in practice requires that refresher courses should be organized through continuing development programmes. All market players need to be reminded, through seminars, conferences, workshops and lectures, that they cannot restrict themselves to conservative approaches in the property industry in this growing analytical world which is fast becoming a global village.

\section{REFERENCES}

Adair, A., McGreal, S. and Webb, J.R. (2006) Diversification effects of direct versus indirect real estate investments in the U.K. Journal of Real Estate Portfolio Management, 12(2), pp. 85-90.

Ajayi, C.A. (1998) Property Investment and Analysis. De-Ayo Publications, Ibadan, Nigeria.

Barry, C.B., Rodriguez, M. and Lipscomb, J.B. (1996) Diversification potential from real estate companies in emerging capital markets, Journal of Real Estate Portfolio Management, 2(2), pp. 107-118.

Bond, S., Karolyi, G. and Sanders, A. (2003) International real estate returns: A multifactor, multi country approach, Real Estate Economics, 31(3), pp. 481-500.

Brown, G.R. (1997) Reducing the dispersion of returns in U.K. real estate portfolios, Journal of Real Estate Portfolio Management, 3(2), pp. 129-140.

Brown, R.J, Li, L.H. and Lusht, K. (2000) A note on intracity geographic diversification of real estate portfolios: evidence from Hong Kong, Journal of Real Estate Portfolio Management, 6(2), pp. 131-140.

Cheng, P. and Liang Y. (2000) Optimal diversification: Is it really worthwhile? Journal of Real Estate Portfolio Management, 6(1), pp. 7-16.

Conover, M., Friday, S. and Sirmans, S. (2002) Diversification benefits from foreign real estate investment, Journal of Real Estate Portfolio Management, 8(1), pp. 17-26.

D'Arcy, E. and Keogh, G. (1998) Territorial competition and property market process: An exploratory analysis, Urban Studies, 35(8), pp. 12151230.

Del Casino, J.J. (1995) Portfolio Diversification Considerations. In Pagliari, J.L. (Jr.) (ed.) The 
Handbook of Real Estate Portfolio Management. Chicago: IRWIN, pp. 912-966.

Giliberto, M. and Hopkins, R.E. (1990) Metro Employment Trends: Analysis and Portfolio Considerations. Salomon Brothers Inc. 14 May, 1990.

Grissom, T.V., Kuhle J.L. and Walther C.H. (1987) Diversification works in real estate too, Journal of Real Estate Portfolio Management, 13(2), pp. 66-67.

Hargitay, S.E. and Yu, S. (1993) Property Investment Decisions: A Quantitative Approach. New York: E\&FN Spon.

Hartzell, D.J., Hekman, J.S. and Miles, M.E. (1986) Diversification categories in investment real estate, AREUEA Journal, 14(2), pp. 230-254.

Hartzell, D., Shulman, J.D. and Wurtzebach, C.H. (1987) Refining the analysis of regional diversification for income producing real estate, Journal of Real Estate Research, 2(2), pp. 8595.

Hoesli, M. and Macgregor, B.D. (2000) Property Investment: Principles and Practice of Portfolio Management. England: Pearson Education Limited.

Keogh, G. and D'Arcy, E. (1994) Market maturity and property market behaviour: A European comparison of mature and Emergent Markets, Journal of Property Research, 11, pp. 215-235.

Lee, S. L. (2005) The return due to diversification of real estate to the U.S. mixed-asset portfolio, Journal of Real Estate Portfolio Management, 11(1), pp. 19-28.

Lim, L.C, Adair, A. and McGreal, S. (2002) Capital flows into the Singapore real estate market: An analysis of the land sales program, Journal of Real Estate Literature, 10(2), pp. 265277.

Lummer, S.L., Riepe, M.W. and Siegel, L.B. (1994) Taming Your Optimizer: A Guide through the Pitfalls of Mean- Variance Optimisation. In Lederman, J. and Klein, R.A. (eds.) Global Asset Allocation: Techniques for Optimising Portfolio Management. New York: John Wiley \& Sons.

Markowitz, H. M. (1952) Portfolio selection, Journal of Finance, 7(1), pp. 77-91.
Markowitz, H. M. (1959) Portfolio Selection: Efficient Diversification of Investments. New York: John Wiley \& Sons.

Miles, M.E. and McCue, T.E. (1982) Historic returns and institutional real estate portfolio, AREUEA Journal, 10(2), pp. 184-198.

Mueller, G.R. (1993) Refining economic diversification strategies for real estate portfolios, Journal of Real Estate Research, 8(1), pp. 55-68.

Mueller, G.R. and Laposa, S.P. (1995) Property-type diversification in real estate portfolios: A size and return perspective, Journal of Real Estate Portfolio Management, 1(1), pp. 39-50.

Olaleye, A. (2004) A case for property data-bank in the Nigerian property market: An empirical study, The Estate Surveyor and Valuer, 27(1), pp. 34-40.

Olaleye, A. (2005) A Study of Real Estate Portfolio Diversification Strategies in the Nigerian Property Market. Unpublished PhD thesis, Department of Estate Management, Obafemi Awolowo University, Ile-Ife.

Olaleye, A., Aluko, B.T. and Oloyede, S.A. (2006) An Evaluation of Property Portfolio Diversification Strategies in Nigeria. Paper presented at the International Symposium on Construction in Developing Economies: New Issues and Challenges, Santiago, Chile. 18-20 January, 2006. Department of Construction Engineering and Management, Pontificia Universidad Catolica de Chile.

Steinert, M. and Crowe, S. (2001) Global real estate investment: characteristics, optimal portfolio allocation and future trends, Pacific Rim Property Research Journal, 7(4), pp. 223-239.

Viezer, T.W. (2000) Evaluating within real estate diversification strategies, Journal of Real Estate Portfolio Management, 6(1), pp. 75-95.

Williams, J.E. (1996) Real estate portfolio diversification and performance of the twenty largest MSAs, Journal of Real Estate Portfolio Management, 2(1), pp. 19-30.

Wolverton, M.L., Cheng, P. and Hardin III, W.G. (1998) Real estate portfolio risk reduction through intracity diversification, Journal of Real Estate Portfolio Management, 4(1), pp. 3541. 
SANTRAUKA

\section{NUOSAVYBĖS RINKOS PRIGIMTIS IR NUOSAVYBĖS PORTFELIO DIVERSIFIKACIJOS STRATEGIJOS PASIRINKIMAS: NIGERIJOS PATIRTIS}

\section{Abel OLALEYE}

Daugiausia dėmesio skiriant Nigerijos nuosavybės rinkai, šiame darbe apžvelgta ir empiriškai išanalizuota ịtaka, kurią, renkantis nuosavybès portfelio diversifikacijos strategijas, daro nuosavybès rinkos prigimtis ir tai, kaip kai kurie rinkos dalyviai suvokia tam tikrus kokybinius veiksnius. Pasitelkus anketas ir pokalbius, apklaustos 28 i nuosavybę investuojančios organizacijos ir 159 nekilnojamojo turto specialistai trijuose pagrindiniuose Nigerijos komerciniuose centruose, t. y. Lagose, Abudžoje ir Port-Harkorte. Dažnių lentelių analizės rezultatai parodè, kad Nigerijos nuosavybės rinka yra kylanti ir, kaip tikimasi, trūko laiko eilučių duomenų, nes rinkoje veikiantys investuotojai buvo smulkūs instituciniai investuotojai. Apskaičiavus vertinimų vidurkị pagal keturių balų skalę, tyrimo metu nustatyti šeši veiksniai, susiję su nuosavybès rinkos prigimtimi, kurie daro reikšmingą įtaką renkantis diversifikacijos strategijas. Jie yra tokie: bendrieji investuotojų lūkesčiai dèl iš diversifikacijos schemos gaunamos naudos, poreikis mažinti operatyvines vadybos išlaidas, valdymo patogumas, operatyvinẻ aplinka, rinkos veikëjų išsilavinimas ir žinios apie alternatyvius diversifikacijos metodus bei prieinamos arba kitaip pasiekiamos žinios rinkoje. Be to, kryžminių lenteliu ir Chi kvadrato kriterijaus rezultatai parodè, kad tarp specialistų išsilavinimo (kvalifikacijos) ir jų pasirinktų diversifikacijos strategijų yra statistiškai reikšmingas ryšys. 